\title{
Phosphorus in the shallow, urban lake subjected to restoration - case study of Lake Domowe Duże in Szczytno
}

\author{
Michał Lopata*, Renata Augustyniak, Jolanta Grochowska, Katarzyna Parszuto, Anna Płachta \\ Department of Water Protection Engineering and Environmental Microbiology, Faculty of Geoengineering, \\ University of Warmia and Mazury in Olsztyn, 1 Prawocheńskiego St., Olsztyn, Poland \\ *Corresponding author, michal.lopata@uwm.edu.pl, phone: (+48) 895233768
}

\begin{abstract}
The paper presents the results of the research on the restoration of the shallow Lake Domowe Duże in Szczytno (area $0.6 \mathrm{~km} 2$, average depth $3.4 \mathrm{~m}$ ). Restoration treatments were carried out in the years 2010-2012 and consisted in the inactivation of phosphorus using polyaluminium chloride. Technical restoration was supported by biomanipulation treatments consisting in stocking the lake with predatory fish. Water quality study were carried out before remediation and annually for a decade (20102019) during and after the application of coagulant. It was shown that the efficiency of removing excess phosphorus from water column was high (decrease from $0.23 \mathrm{mgP}$ L-1 to $0.05 \mathrm{mgP}$ L-1). The effects achieved during the coagulant application were maintained for 5 years after the end of the project. Currently, the phosphorus pool is still twice as low as before the treatments, but it is gradually increasing. The main external factor limiting permanent improvement of water quality is the open hydrological system and transport of biogenic matter by surface inflows draining anthropogenically transformed areas. Maintaining permanent improvement of water quality will require continuation of restoration measures.
\end{abstract}

Key words: lakes restoration, trophic status, phosphorus inactivation, polyaluminum chloride

\section{Introduction}

The economic development in Poland over the last two decades has been accompanied by a significant improvement in the efficiency of water and wastewater management. As a result of modernization and investment works undertaken as part of the government program "National Program for Municipal Wastewater Treatment", the load of pollutants reaching the environment was significantly reduced (PGW Wody Polskie 2018). In particular, the positive effects of these actions are felt by urban lakes, once exposed to an excessive load of biogenic matter of sewage origin (Soszka et al. 2016). Unfortunately, the level of pollution of many municipal water bodies does not always allow spontaneous improvement of water quality (Cullen and Forsberg 1988, Jeppesen et al. 2005, 2007, Rosińska et al. 2018). Moderately polluted deep-water stratified lakes are usually able to withdraw a significant portion of biogenic matter from circulation and deposit it in periods of thermal stratification below the trophic zone (Kajak 2001). Theoretically, when the condition of limited anthropopressure is met, it should allow for obtaining acceptable water quality in the surface layer and retain recreational values.

In the case of shallow lakes, especially large waterbodies, with high water circulation dynamics, the pool of anthropogenic pollutants, even after the external loading ceases, determines the progress of eutrophication many years after the sewage cut-off. Therefore, to achieve the desired environmental goal more often than for deep lakes it is necessary to undertake restoration treatments. Numerous examples of such activities indicate that with the appropriate reclamation technique, a significant improvement in water quality can be achieved (Dondajewska et al. 2018, Łopata et al. 2020a). However, there are few studies indicating the degree of persistence of the effects achieved over the years. Postcompletion monitoring usually lasts $1-2$ years, in accordance with the formal requirements of the remediation 
program. Knowledge about the directions of biogeochemical changes in the lake ecosystem over several years after the restoration process is, however, crucial for identifying the mechanisms of stabilization - or its lack - of improved trophic state.

The purpose of this work was to determine the durability of the effects of reclamation of Lake Domowe Duże in Szczytno, restored in 2010-2012 by phosphorus inactivation using polyaluminium chloride.

\section{Material and Methods}

\section{Experimental Lake}

Lake Domowe Duże and Domowe Małe are the main surface water resources in the city of Szczytno. Hydrologically these lakes are open. From the west, they are fed by a tributary " 1 " originating in the nearby Lake Szczycionek (8.9 ha), while the outflow via the Kanal Domowy communicates with the Sawica River, which is a left-bank tributary of the Omulew River (Fig. 1). An additional small inflow " 2 " is a drainage the city from the south. The topographic catchment area of the lake is about $11.6 \mathrm{~km}^{2}$.

Lake Domowe Duże is a medium-sized (about $60 \mathrm{ha}$ ), shallow (maximum depth of $7.2 \mathrm{~m}$ ), strongly elongated along the W-E axis. Basic morphometric data (historical studies of the Inland Fisheries Institute, 1964 and modern data form University of Warmia and Mazury in Olsztyn from 2012) are presented in Table 1.

Lake Domowe Duże together with Lake Domowe Małe is a valuable natural and recreational resource for the local community (Łopata et al. 2016). Unfortunately, like many other water reservoirs, this lake served as a sewage receiver - municipal, industrial and even cooling water from local plants. In addition, the lake was used as a source of industrial water, which contributed to a catastrophic reduction of the water level for several years (over 1m). All these reasons caused a deep degradation of the lake, which ceased to be a recreational function and became hypertrophized (Gawrońska and Lossow 2005).

At the beginning of this century, a thorough modernization of the city's water and sewage network was carried out, and sewage pollutants were cut off. Currently, the lake is only a receiver of rainwater from some urban areas and natural tributaries. However, due to the very high degree of susceptibility to degradation (Łopata et al. 2013), even such an inflow of waters from anthropogenically changed catchment is a potential threat to the lake. A further step towards improving water quality was the work of technical restoration (phosphorus inactivation) supported by biological methods (intensive restocking with predatory fish).

\section{Restoration procedure}

The restoration of Lake Domowe Duże began in 2010 and continued until 2012. The three-year revitalization program included the annual spring application of a preparation binding excess phosphorus available for hydrobionts. Aluminum chloride-based coagulant (PAX 18) was used in a total of $26 \mathrm{~g} \mathrm{Al} \mathrm{m}^{-2}$ which corresponded to about 3 tons of commercial product per hectare of lake. The dose of coagulant was selected according to the buffer properties of the water, the level of phosphorus lake water content and the properties of bottom sediments being an internal source of this element, as suggested by Gawrońska et al. (2001) and Rydin and Welch (1998).

The restoration treatments were carried out in accordance with the recommended period of natural water circulation (Cooke et al. 2005). The spring turnover period was chosen, before the growing season. The coagulant was evenly distributed over the lake surface. A detailed description of the application procedure is given in the work of Łopata et al. (2013).

The works supporting technical reclamation were carried out in parallel and consisted in changing the species of fish that were stocked from cyprinids to predators (pike Esox lucius and pikeperch Sander lu-

Table 1. Morphometric data of Lake Domowe Duże in Szczytno.

\begin{tabular}{cccc}
\hline & Unit & \multicolumn{2}{c}{ Value } \\
\cline { 3 - 4 } Parameter & & IFI $\mathbf{1 9 6 4}$ & UWM 2012 \\
\hline Area & ha & 62.1 & 58.7 \\
Maximum depth & $\mathrm{m}$ & 5.4 & 7.2 \\
Mean depth & $\mathrm{m}$ & 2.8 & 3.4 \\
Shore development index & - & 1.90 & 1.87
\end{tabular}




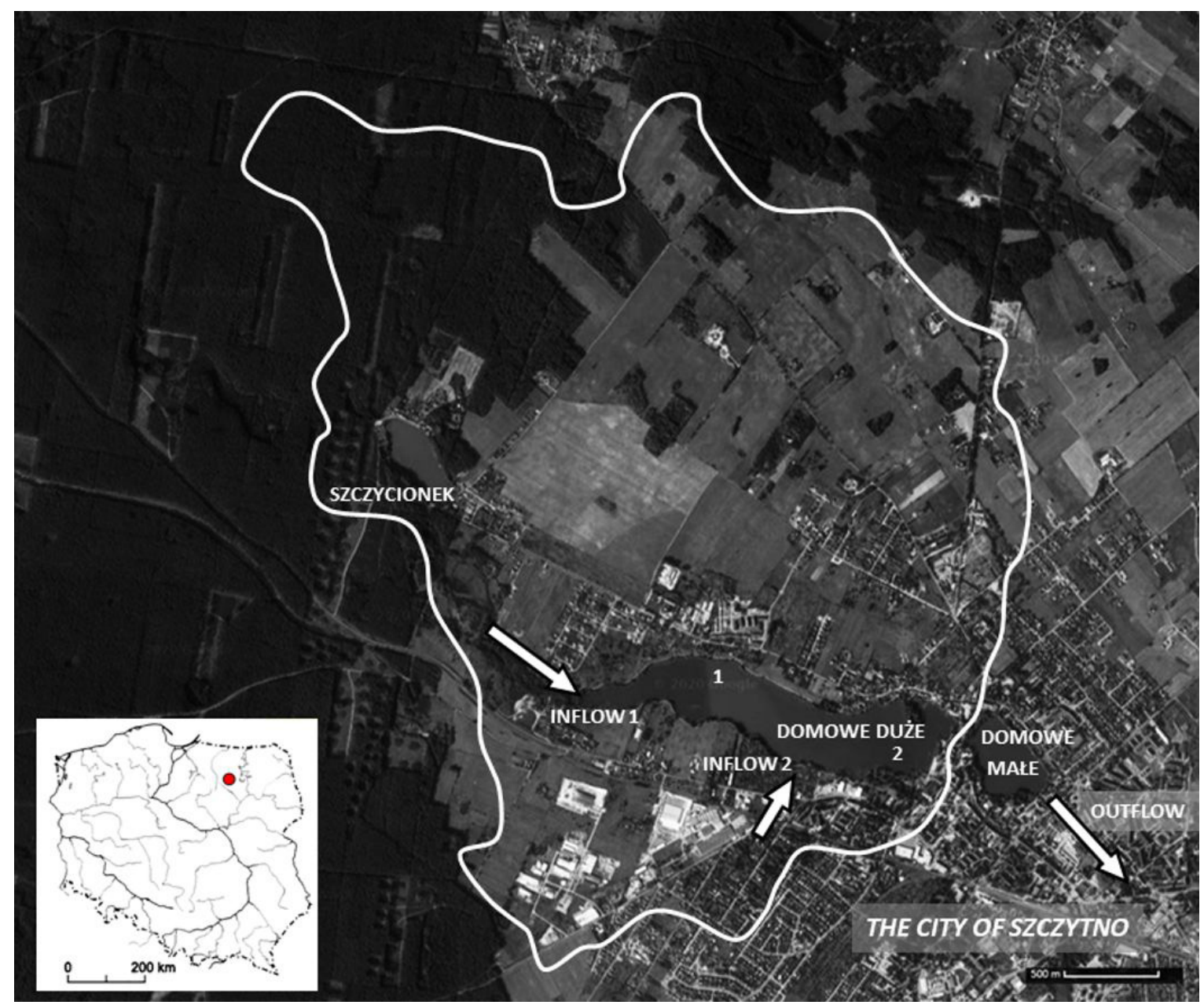

Fig. 1. Lakes Domowe in Szczytno - location, hydrological system (marked with arrows), catchment range (marked with a white line) and sampling stations $(1,2)$. Orthophotomap from Google maps

cioperca). This stocking policy of the fishing authority of the lake (The Polish Angling Association) is continued today. Northern is stocked as a fry with an average of about 400 individuals per hectare yearly (148-579 ind./ha in 2010-2020). Summer fingerlings of pikepearch are stocked at approximately 70 individuals per hectare yearly (68-93. ind./ha in 2010-2020).

\section{Sampling and Analytical Methods}

The study of water parameters was conducted from spring to autumn during 10 research years (2010 - 2019). Water samples were collected 3-4 times in the season using a Ruttner sampler. Surface water $(1 \mathrm{~m}$ below the water table) and bottom water ( $1 \mathrm{~m}$ above sediments) were collected for analyses from two sampling stations (maximum depth $5.4 \mathrm{~m}$ and $3.8 \mathrm{~m}$ respectively, respectively - Fig. 1). Comparative data before reclamation came from 2005, and was obtained in an analogous manner. Water flowing into the lake was also included in the study. Water flow measurements were made 4-6 times in the season using a Valeport 801 electromagnetic flowmeter, Sontek FlowTracker2 acoustic flowmeter or volumetric method at dates consistent with lake examinations. At the peak of the growing season (August), the range of submerged vegetation was also observed using a steel anchor with a pulled rope.

In the obtained water, a number of determinations of water quality indicators were carried out (i.a. total and mineral phosphorus, total and mineral nitrogen, chlorophyll a, $\mathrm{BOD}_{5}$, total organic carbon, in accordance with common standards (APHA 2005). This paper presents changes in the in the main element responsible for eutrophication - phosphorus (total P). An analysis of changes in light conditions in the lake was also made as an environmental effect of the measures taken - based on collected measurements of water 
transparency using a Secchi disk.

\section{Results and Discussion}

The phosphorus inactivation method assumes elimination of excess of this element from the water column due to direct coagulant interaction (in the case of surface application), as well as suppression of phosphorus release from bottom sediment (after forming a barrier from coagulant flocs at the bottom of the lake). It is widely believed that the use of a coagulant with high affinity for phosphorus very quickly leads to a decrease in the pool of this element available to primary producers (Cooke et al. 2005, Klapper 1991, 2003).

The results of the monitoring of Lake Domowe Duże restoration in Szczytno confirm this thesis. As indicated in Figure 2, a sharp decrease in the phosphorus concentration in the trophic layer was already observed in the first year of reclamation. Before the procedures, Lake Domowe Duże was characterized by a very high level of total phosphorus concentration - in the surface layer it was $0.2-0.3 \mathrm{mgP} \mathrm{L}^{-1}$, and in the bottom layer even above $0.25 \mathrm{mgP} \mathrm{L}^{-1}$. Such concentrations correspond to advanced hypertrophy (OECD 1982). In 2010, the average phosphorus concentration reached 0.13 $\mathrm{mgP} \mathrm{L}{ }^{-1}$, which is only $50 \%$ of the current pool. The next 2 years of treatments brought consistent decrease in the concentration of this element to a value below $0.1 \mathrm{mgP}$ $\mathrm{L}^{-1}$, widely regarded as the upper limit of eutrophies. In the first year after the completion of the restoration works (2013), there was a further, significant decline in the phosphorus concentration to $0.06 \mathrm{mgP} \mathrm{L}^{-1}$ (i.e. by about 33\% compared to the state achieved in the last year of the reclamation). This change initiated a fiveyear period of persistence of stable, low (0.05-0.06 mgP $\left.\mathrm{L}^{-1}\right)$ phosphorus concentrations in the depth of Lake Domowe Duże. In the years 2018-2019, phosphorus concentrations increased, both in surface and bottom waters of the studied lake (Fig. 2).

The issue of sustainability of restoration effects is often analyzed when planning, implementing or reporting restoration work. In general, researchers agree that with the correct course of the water reservoir revitalization project by the method of phosphorus inactivation, the improved water quality is maintained for several years (Cooke et al. 2005, Lewandowski et al. 2003). The case of the Lake Domowe Duże in Szczytno does not differ from this pattern. It is a shallow lake, with high dynamics of water masses, unable to effectively withdraw matter into the bottom layers, just like stratified lakes. Thus, the five-year period mentioned above for the maintenance of the highest restoration effects can already be considered satisfactory from the point of view of project evaluation. It is of course worth mentioning that, despite the tendency to increase the abundance of phosphorus observed in 2018-2019, the lake is still in good condition without cyanobacterial blooms and serves as a bathing beach. Analysis of environmental conditions based on water transparency (Fig. 3) showed that the studied reservoir maintains improvement until the end of the research period (average water transparency in the growing season $>1.0 \mathrm{~m})$. At

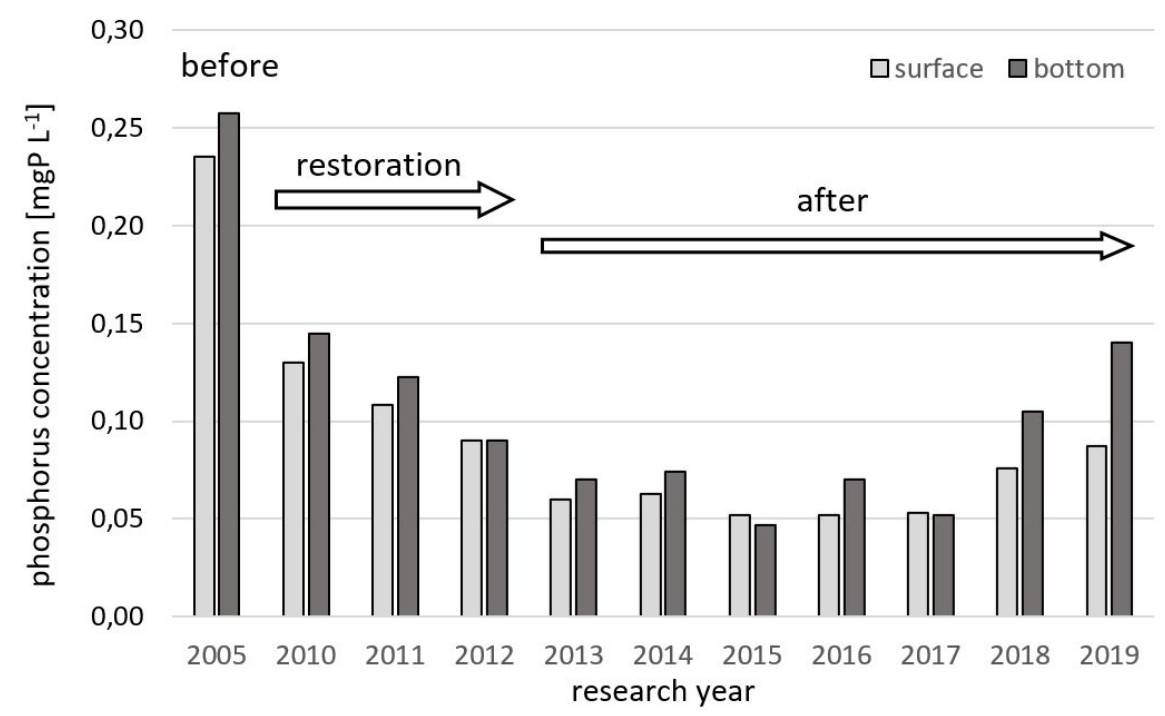

Fig. 2. Changes in total phosphorus average concentration during experimental period (all tests in each season - mean of two sampling stations) 
the time of writing this manuscript (summer 2020), this level is still being reached.

The lake ecosystem subjected to violent interference, which is the reclamation with chemical phosphorus binding, usually reacts by the step decrease in the trophy level that occurs immediately after the application of the preparation. In subsequent months or growing seasons after the end of dosing, lake response scenarios may be different. With a high degree of isolation of the lake from external sources of pollution and a large depth, the symptoms of recurrent eutrophication may appear only after over a dozen years (Grochowska et al. 2019). In theory, the more the lake is exposed to the supply of biogenic matter from the catchment, the faster the return of excessive production of indigenous organic matter by the regenerating algae populations. Therefore, the key factor for maintaining the longest possible period of positive changes in the lake subjected to restoration is the elimination of all sources of pollution that can be removed.

Lake Domowe Duże did not fulfill the role of a sewage receiver at the beginning of the restoration period. However, the catchment area of this basin, consisting mainly of urban buildings and arable fields, does not allow full isolation from the inflow of external nu- trient load. The existing two natural surface tributaries drain the anthropogenic transformed areas, so the hydrological conditions of the reservoir will contribute to the gradual enrichment of the ecosystem with nutrients. They are currently the main source of biogenic pollution. Throughout the research period, the inflow from Szczycionek (inflow 1), although gradually disappeared due to the increasing drought in the region, but the second inflow showed year-round activity. The average delivery conditions for the phosphorus load in the years covered by the survey are presented in Table 2 .

Comparing the above data to the critical load level determined according to Vollenweider (1968), which for Lake Domowe Duże is $104 \mathrm{mg} \mathrm{m}^{-2}$ per year, it should be emphasized that, despite isolation from point sources of pollution, it is responsible for the level of pollution already considered dangerous for the lake. In addition, there are other sources of biogenic pollution (surface runoff from the direct catchment, atmospheric deposition, bathing beach, fishing groundbaits). Although in relation to the inflow of natural watercourses they have marginal significance, they nevertheless can affect the increase of phosphorus concentrations in water (especially in dry years).

In addition to the external causes of the gradual

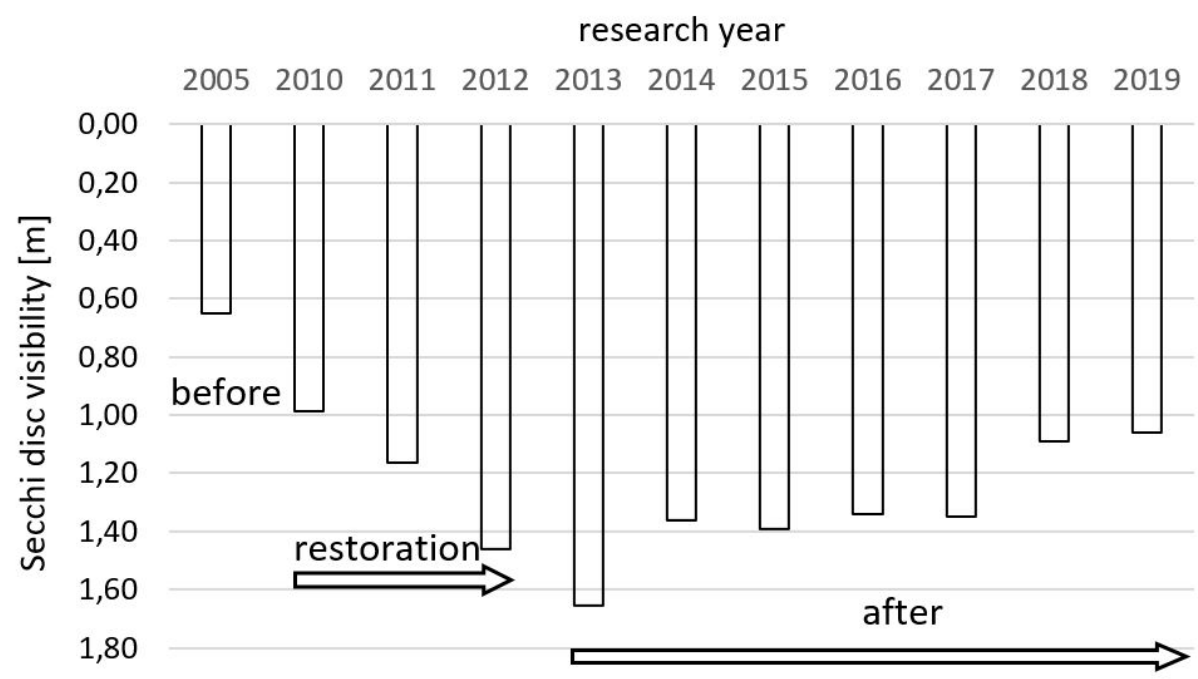

Fig. 3. Mean water transparency in Lake Domowe Duże in Szczytno during experimental period

Table 2. Characteristics of the inflows of Lake Domowe Duże as a source of phosphorus.

\begin{tabular}{|c|c|c|}
\hline \multicolumn{1}{|c}{ Parameter } & Inflow 1 & Inflow 2 \\
\hline Flow $\left[\mathrm{L} \mathrm{s}^{-1}\right]$ & $0.0-11.0$ & $0.1-18.3$ \\
\hline Phosphorus loading $\left[\mathrm{kg} \mathrm{d}^{-1}\right]$ & $0.0-0.247$ & $0.001-0.965$ \\
Average annual supply $\left[\mathrm{kg} \mathrm{yr}^{-1}\right]$ & 50.96 & 78.87 \\
\hline
\end{tabular}


disappearance of the effects of lake restoration by the phosphorus inactivation method, there are also internal mechanisms. The coagulant layer at the bottom of the lake with time loses its insulating properties. It is caused by various factors: defragmentation due to the activity of benthic organisms (especially fish), natural physical factors (strong waving, resuspension of bottom sediments), the natural process of sinking coagulant flocs in a muddy, unstable bottom even to a depth of over a dozen $\mathrm{cm}$ (Łopata et al. 2020b), as well as processes described in the literature as the aging of flocs (Berkowitz et al. 2005), leading to a partial breakdown of connections between the sorption factor (in this case aluminum) and phosphorus. The above processes are more or less likely to occur in practically every lake subjected to restoration treatments. Their intensity will depend on the individual characteristics of the reservoir. Lake Domowe Duże is a highly silted and very shallow reservoir, which contributes to the loss of coagulant barrier continuity due to the mechanisms described above. The lake's ichthyofauna still needs to be improved. Longterm stocking of carp fish is no longer practiced (Łopata et al. 2013), but their effect is the presence of abundance of benthic spieces in the lake (especially bream Abramis brama, but also common carp Cyprinus carpio). A clear increase in phosphorus concentration in the bottom layers of the lake in recent years, it is probably the result of the bioturbation by benthic fish, which are currently intensifying with a decrease in water level due to the constantly deteriorating water balance of the Lake Domowe Duże.

In turn, the factor acting in favor of maintaining an improvement in water quality in such conditions is the expansion of submerged vegetation. Its rebirth in water is one of the key ecological factors for maintaining good ecological status in eutrophic lakes (Zhang et al. 2010, Sondergaard et al. 2010). Our field observations indicate that the populations of submerged vegetation after the reclamation period remain stable every year and their range usually reaches or even exceeds a depth of $2.0 \mathrm{~m}$. Currently, it is the depth corresponding to twice the range of the Secchi disc (Fig. 3), so submerged vegetation uses maximum light conditions. During the recent decrease water level in the lake, this is conducive to expanding the range of its habitats. We estimate that the current level of bottom coverage with submerged macrophytes (mainly occurring species are Potamogeton pectinatus, Elodea canadensis and Ceratophyllum demersum) is $20-25 \%$, in contrast to the period before restoration treatments, when underwater vegetation in the Domowe lakes in Szczytno occurred at a marginal level (Ciecierska and Dynowski 2009, unpublished data, Łopata et al. 2013). According to literature data (Yanran et al. 2012), this level of underwater vegetation expansion already has the potential to effectively compete for nutrients with phytoplankton and participate in the lake reconstruction process.

The research results presented above show that, despite the significant improvement in water quality, Lake Domowe Duże in Szczytno is not yet in a state of stable equilibrium appropriate for clear-water lakes. The shallow depth of water and the decreasing water resources limit the possibility of accepting the external load of biogenic pollutants without consequences in the form of eutrophication symptoms. The lake requires further protection.

\section{Conclusions}

Restoration of polymictic lakes is more difficult than stratified waterbodies. The shallow Lake Domowe Duże in Szczytno responded positively to phosphorus inactivation procedures carried out in 2010, 2011 and 2012. The significant reduction of bioavailable phosphorus allowed to eliminate persistent cyanobacterial blooms, improve water quality and lighting conditions and restore the lake's usability. The effectiveness of the coagulant in controlling phosphorus in the lake was noticeable for several years, after which the concentrations of this element began to gradually increase. Seven years after the end of the restoration, the water content of phosphorus remains lower than before the treatments. However, the upward trend indicates the need to prepare for further stages of lake revitalization. The ecosystem's likely return to the turbid state in subsequent years indicates the key role of environmental monitoring of the lake and its tributaries for the preparation of correct plans for further revitalization activities.

\section{Acknowledgements}

The study was financially co-supported by the Minister of Science and Higher Education according to decision number 6722/IA/SP/2017.

We would like to thank Grzegorz Wiśniewski and Bartosz Pietruszyński for field work assistance.

\section{References}

APHA (American Public Health Association), 2005, Stan- 
dard methods for the examination of water and wastewater, 21 st ed. Washington (DC).

Berkowitz J., Anderson M.A., Amrhein C, 2006, Influence of aging on phosphorus sorption to alum floc in lake water, Wat Res, 40: 911-916.

Cooke G.D., Welch E.B., Peterson S.A., Nichols S.A., 2005, Restoration and Management of Lakes and Reservoirs, Taylor \& Francis/CRC Press.

Cullen P., Forsberg C., 1988, Experiences with reducing point sources of phosphorus to lakes, Hydrobiologia 170: 321-336

Dondajewska R., Kozak A., Kowalczewska-Madura K., Budzyńska A., Podsiadłowski S., Tomkowiak A., 2018, The response of a shallow hypertrophic lake to innovative restoration measures - Uzarzewskie Lake case study, Ecological Engineering 121: 72-82, DOI 10.1016/j.ecoleng.2017.07.010.

Gawrońska H., Brzozowska R., Grochowska J., Lossow K., 2001, Effectiveness of PAX and PIX coagulants in phosphorus reduction in a lake - laboratory experiments, Limnological Review 1: 73-82.

Gawrońska H.,Lossow K., 2005, Restoration of the Domowe Lakes in Szczytno - history and plans, Limnological Review 5: 69-73.

Grochowska J., Augustyniak R., Łopata M., Parszuto K., Tandyrak R., Płachta A., 2019, From saprotrophic to clear water status: the restoration path of a degraded urban lake, Water Air Soil Pollut, 230, 94, doi. org/10.1007/s11270-019-4138-5.

Jeppesen E., Sřndergaard M., Jensen J. P., Havens K. E., Anneville O., Carvalho L., Coveney M. F., Deneke R., Dokulil M. T., Foy B., 2005), Lake responses to reduced nutrient loading - an analysis of contemporary long-term data from 35 case studies, Freshw. Biol, 50: 1747-1771.

Jeppesen E., Sřndergaard M., Meerhoff M., Lauridsen T. L., Jensen J. P., 2007, Shallow lake restoration by nutrient loading reduction - Some recent findings and challenges ahead, Hydrobiologia, 584: 239-252.

Kajak Z., 2001, Hydrobiology - limnology. Inland water ecosystems, PWN, Warsaw, (in Polish)

Klapper H., 1991, Control of eutrophication in inland waters, Ellis Hornwood, New York.

Klapper H., 2003, Technologies for lake restoration, Journal of Limnology, 62(1): 73-90.

Lewandowski J., Schauser I., Hupfer M, 2003, Long term effects of phosphorus precipitations with alum in hypereutrophic Lake Süsser See (Germany), Water Research, 37: 3194-3204.

Łopata M., Gawrońska H., Wiśniewski G., Jaworska B., 2013, Restoration of two shallow, urban lakes using the phosphorus inactivation method - preliminary results, Water Science and Technology 68(10): 2127 2135.
Łopata M., Wiśniewski G., Parszuto K., Dunalska J. A., 2016, From restoration to revitalization: How to recover recreational values of urban lakes. A case study of Lake Domowe Duże in Szczytno, Polish Journal of Natural Sciences, 31(3): 471-483.

Łopata M., Augustyniak R., Grochowska J. K., Parszuto K., Tandyrak R., 2020a, Selected aspects of lake restorations in Poland, In: Korzeniewska, E., \& Harnisz, M. (eds): Polish River Basins and Lakes - Part II: The Handbook of Environmental Chemistry 87. Springer International Publishing AG, 327-352. doi. org/10.1007/978-3-030-12139-6_15.

Łopata M., Augustyniak R., Grochowska J. K., Parszuto K., Tandyrak R., Wiśniewski G., 2020b, Behavior of aluminum compounds in soft-water lakes subjected to experimental reclamation with polyaluminium chloride. Water Air Soil Pollut, 231, 358 doi. org/10.1007/s11270-020-04708-6.

OECD, 1982, Eutrophication of Waters - Monitoring, Assessment and Control. The Organisation for Economic Cooperation and Development (OECD), Paris, pp.154.

Rosińska J., Kozak A., Dondajewska R., KowalczewskaMadura K., Gołdyn R., 2018, Water quality response to sustainable restoration measures - case study of urban Swarzędzkie Lake, Ecological Indicators 84: 437-449.

Państwowe Gospodarstwo Wodne Wody Polskie, 2018, Gospodarka ściekowa w Polsce w latach 20152016. https://www.kzgw.gov.pl/files/kposk/06-materialy/ broszura_2015_2016.pdf

Rydin E., Welch E. B., 1998, Aluminum dose required to inactivate phosphate in lake sediments, Wat. Res, 32(10): 2969-2976.

Soszka H., Kolada A., Pasztelaniec A., Ochocka A., Kutyła S., Biełczyńska A., 2016, Development of a collective assessment of the condition of lakes from 2010-2015 (in Polish). Instytut Ochrony Środowiska Polski Instytut Badawczy: 1-14.

Sřndergaard M., Johansson L.S., Lauridsen T.L., Jřrgensen T.B., Liboriussen L., Jeppesen E., 2010, Submerged macrophytes as indicators of the ecological quality of lakes. Freshwater Biol. 55: 893-908.

Yanran D., Chenrong J., Liang Wei L., Shenghua H., Zhenbin W., 2012, Effects of the submerged macrophyte Ceratophyllum demersum L. on restoration of a eutrophic waterbody and its optimal coverage, Ecol. Eng. 40: 113-116.

Zhang S.-y., Liu A.-f., Ma J.-m., Zhou Q.-h., Xu D., Cheng S.-p., Zhao Q., Wu Z.-b., 2010, Changes in physicochemical and biological factors during regime shifts in a restoration demonstration of macrophytes in a small hypereutrophic Chinese lake, Ecol. Eng. 36: 1611-1619. 